DNA damage among thyroid cancer and multiple cancer cases, controls, and long-lived individuals

A. J. Sigurdson, M. Hauptmann, B. J. Alexander, M. M. Doody, C. B. Thomas, J. P. Struewing, I. M. Jones

August 24, 2004

Mutation Research 
This document was prepared as an account of work sponsored by an agency of the United States Government. Neither the United States Government nor the University of California nor any of their employees, makes any warranty, express or implied, or assumes any legal liability or responsibility for the accuracy, completeness, or usefulness of any information, apparatus, product, or process disclosed, or represents that its use would not infringe privately owned rights. Reference herein to any specific commercial product, process, or service by trade name, trademark, manufacturer, or otherwise, does not necessarily constitute or imply its endorsement, recommendation, or favoring by the United States Government or the University of California. The views and opinions of authors expressed herein do not necessarily state or reflect those of the United States Government or the University of California, and shall not be used for advertising or product endorsement purposes. 


\title{
DNA damage among thyroid cancer and multiple cancer cases, controls, and long-lived individuals
}

\author{
Alice J. Sigurdson ${ }^{1}$, Michael Hauptmann ${ }^{2}$, Bruce H. Alexander ${ }^{3}$, Michele Morin Doody ${ }^{1}$, \\ Cynthia B. Thomas ${ }^{4}$, Jeffery P. Struewing ${ }^{5}$, Irene M. Jones ${ }^{4}$
}

\begin{abstract}
${ }^{1}$ Radiation Epidemiology Branch and ${ }^{2}$ Biostatistics Branch, Division of Cancer Epidemiology and Genetics, National Cancer Institute, NIH, DHHS, 6120 Executive Boulevard, Bethesda, Maryland, 20892-7238; ${ }^{3}$ Division of Environmental and Occupational Health, University of Minnesota, Minneapolis, MN, 55455; ${ }^{4}$ Lawrence Livermore National Laboratory, Livermore, CA; ${ }^{5}$ Laboratory of Population Genetics, Center for Cancer Research, National Cancer Institute, NIH, DHHS, Building 41, D702, Bethesda, Maryland, 20892-5060.

Emails: Alice Sigurdson: sigurdsa@mail.nih.gov, Michael Hauptmann: hauptmam@mail.nih.gov, Bruce Alexander: balex@umn.edu, Michele Doody: doodym@mail.nih.gov, Cynthia Thomas: thomas5@1ln1.gov, Jeffery Struewing: struewij@mail.nih.gov, Irene Jones: jones20@1ln1.gov.
\end{abstract}

Key Words: Comet assay, multiple cancers, genetic variation, risk factors, hyper-normal controls

$\begin{array}{llr}\text { Word Count: } & \text { Abst. }= & 285 \\ & \text { Text }= & 3283\end{array}$

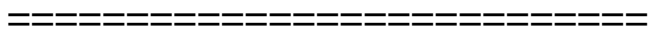

Correspondence and reprint requests to: Alice Sigurdson, Radiation Epidemiology Branch, Division of Cancer Epidemiology and Genetics, National Cancer Institute, NIH, DHHS, 6120 Executive Boulevard, EPS 7092, MSC 7238, Bethesda, MD 20892-7238.

TEL: $\quad 301.594 .7911$

FAX: $\quad 301.402 .0207$

EMAIL: $\quad$ sigurdsa@mail.nih.gov 


\begin{abstract}
Variation in the detection, signaling, and repair of DNA damage contributes to human cancer risk. To assess capacity to modulate endogenous DNA damage among radiologic technologists who had been diagnosed with breast cancer and another malignancy (breast-other; $n=42$ ), early-onset breast cancer (early-onset, age $\leq 35 ; n=38)$, thyroid cancer $(n=68)$, long-lived cancer-free individuals (hyper-normals; $n=20)$ and cancer-free controls $(n=49)$ we quantified DNA damage (single strand breaks and abasic sites) in untreated lymphoblastoid cell lines using the alkaline comet assay. Komet ${ }^{\mathrm{TM}}$ software provided comet tail length, \% DNA in tail (tail DNA), comet distributed moment (CDM), and Olive tail moment (OTM) summarized as the geometric mean of 100 cells. Category cut-points (median and $75^{\text {th }}$ percentile) were determined from the distribution among controls. Tail length (for $\geq 75 \%$ vs. below the median, age adjusted) was most consistently associated with the highest odds ratios in the breast-other, early-onset, and thyroid cancer groups (with risk increased 10-, 5- or 19-fold, respectively, with wide confidence intervals) and decreased risk among the hyper-normal group. For the other three Comet measures, risk of breast-other was elevated approximately three-fold. Risk of early-onset breast cancer was mixed and risk of thyroid cancer ranged from null to a two-fold increase. The hyper-normal group showed decreased odds ratios for tail DNA and OTM, but not CDM. DNA damage, as estimated by all Comet measures, was relatively unaffected by survival time, reproductive factors, and prior radiation treatment. We detected a continuum of endogenous DNA damage that was highest among cancer cases, less in controls, and suggestively lowest in hyper-normal individuals. Measuring this DNA damage phenotype may contribute to the identification of susceptible sub-groups. Our observations require replication in a prospective study with a large number of pre-diagnostic samples.
\end{abstract}




\section{Introduction}

There is considerable evidence that individual variation in the detection, signaling, toleration, and repair of DNA damage (from internal and external exposures and intrinsic instability of DNA) contributes to human cancer risk (reviewed in [1-6]). Several studies (with sample sizes in excess of 20 cases and 20 controls) have reported increased breast [7,8] and bladder [9] cancer risks associated with higher DNA damage measured by the comet assay [10]. In these studies elevated endogenous damage and post-mutagen challenge damage levels were associated with increased cancer risk. These results indicate that elevated endogenous damage is itself a risk factor, and are consistent with the notion that measures of endogenous damage are correlated with damage repair capability after an exogenous challenge.

We characterized risk of solid cancer associated with ability to limit DNA damage from endogenous DNA metabolic processes among persons with selected malignancies, compared to controls by quantifying single strand DNA breaks (SSB) and abasic sites of untreated cell lines using the alkaline comet assay. This assay provides a measure of the net effect of each cell's antioxidant and base excision repair pathway capacity to prevent and repair oxidative DNA damage, the major endogenous source of genomic instability [11-13]. In addition, we compared controls to individuals who were long-lived, cancer-free and reported no invasive cancer in first degree relatives. All the cases and controls were part of a larger, ongoing study of cancer and other health outcomes among radiologic technologists exposed through their occupation to low-dose radiation from medical sources.

\section{Methods}




\subsection{Study population}

In 1982, the U. S. National Cancer Institute, in collaboration with the University of Minnesota and the American Registry of Radiologic Technologists, initiated a study of cancer incidence and mortality among 146,022 U.S. radiologic technologists who were certified for at least two years between 1926 and 1982. The cohort members are predominantly female (73\%) and their current mean age is 55 years [14]. The study has focused on cancers of the thyroid gland (papillary histology) and the female breast as these tissues are thought to be particularly radiation sensitive $[15]$.

\subsection{Cancer confirmation and recruitment.}

Cancer(s) reported on a study questionnaire were confirmed, and individuals were invited to provide a peripheral blood sample. At that time, for the rare persons with multiple cancers (including cancer of the breast and a second primary cancer), early-onset breast cancer (age 35 or younger) and papillary thyroid cancer, a portion of the sample was used to create EBV transformed lymphoblastoid cell lines. We sought to establish a lymphoblastoid cell line resource of approximately 40 to 60 individuals per cancer group. Approximately 50 cancer-free female controls were frequency matched on age ( \pm 5 years) to the case groups. We also recruited 20 female radiologic technologists who were over 70 years of age, had never had any cancer (defined to include non-melanoma skin cancer), and had not reported any first degree relative with a cancer diagnosis at the time of blood collection. We referred to these individuals as "hyper-normal", akin to the naming convention used for similar selection strategies in related study designs [16] reasoning they may have a further decrease in background cancer risk compared to controls. All of the cases and controls provided informed consent and responded to a telephone interview that collected current cancer risk factors and family history of cancer. This study has been approved 
annually by the human subjects review boards of the National Cancer Institute and the University of Minnesota. Studies conducted at Lawrence Livermore National Laboratory (LLNL) have been approved annually by the LLNL Institutional Review Board.

\subsection{Samples}

A lymphoblastoid cell line was prepared by Epstein Barr virus transformation of peripheral blood lymphocytes obtained from each subject. All fresh samples were successfully transformed and each line was cryopreserved. For this study, the samples were tracked by a unique ID code, and investigators were blinded to case-control and case-group status. Cell lines were cultured in RPMI 1640 supplemented with 15\% serum (Fetal Clone III, HyClone, Logan, Utah) and 2mM glutamine

prior to analysis. Aliquots of all cell lines were cryopreserved at LLNL. The period of culture prior to analysis varied among cell lines, from about 3 to 5 weeks, depending on the growth rate of the cell line and the proportion of viable cells during early culture. For quality assessment, replicate samples of five individuals were included, some in the same shipment, others in separate shipments. In addition, 16 cultures were repeated with personnel blinded to results of the first assay.

\subsection{Measurement of DNA damage.}

Cells were in exponential growth phase at the time of assessment of DNA damage. Viability was determined by Trypan blue dye exclusion. The alkaline comet assay was used to measure DNA damage according to Singh et al. [10] with slight modifications. Frosted end glass microscope slides were first coated with $1.0 \%(\mathrm{w} / \mathrm{v})$ agarose and allowed to dry. Cells were suspended in $0.5 \%$ low melting point agarose and spread on each of two slides with a coverslip. After the agarose hardened, the coverslip was removed and slides were treated in the dark at $4^{\circ} \mathrm{C}$ with lysis buffer (1\% Triton X-100, 10\% DMSO, 89\% stock lysing solution: $2.8 \mathrm{M} \mathrm{NaCl,} 0.1 \mathrm{M}$ 
$\mathrm{Na}_{2}$ EDTA, 0.01M Trizma Base) at least overnight, then rinsed in 0.4 M Tris, $\mathrm{pH}$ 7.5. Slides were then placed in the electrophoresis unit and covered with a fresh solution of $300 \mathrm{mM} \mathrm{NaOH}, 1 \mathrm{mM}$ EDTA, final $\mathrm{pH}>13.0$, for $60 \mathrm{~min}$. A split, balanced slide layout design was used (one slide from each sample was in each of two rows, but in different electrophoresis runs) to attend to position effects and run to run variation. The slides were electrophoresed at $0.92 \mathrm{~V} / \mathrm{cm}$ with current adjusted to 300 mamps for $25 \mathrm{~min}$. The slides were washed in $0.4 \mathrm{M}$ Tris, $\mathrm{pH} 7.5$, placed for $5 \mathrm{~min}$. in cold methanol and allowed to dry. Each slide was stained with ethidium bromide $(2 \mu \mathrm{g} / \mathrm{ml})$ for $5 \mathrm{~min}$. Images of 50 cells on each of 2 slides were captured and comet parameters determined using Komet4.0@: Image Analysis and Data Capture software (Kinetic Imaging, Ltd., Merseyside, England). Four comet parameters were analyzed; the definitions used by Komet4.0 are: "Tail DNA" is the percent of DNA (fluorescence) in the tail. "Tail length" is the length of the tail in $\mu \mathrm{m}$, measured from the leading edge of the head; Comet Distributed Moment (CDM), also referred to as comet moment (16), is the moment of fluorescence of the whole comet and does not distinguish head and tail; Olive Tail Moment (OTM) is the percentage of DNA in the tail (tail DNA) times the distance between the means of the tail and head fluorescence distributions, where "mean" is the profile center of gravity, divided by 100. Both CDM and OTM are expressed in arbitrary units. All four parameters describe the amount of endogenous DNA damage and therefore high values are thought to correspond to an increased amount of cellular DNA strand breakage and/or alkali-labile sites.

\subsection{Statistical analysis}

We used the geometric mean of tail length, tail DNA, CDM and OTM of 100 randomly selected cells per subject as a summary measure to reduce the influence of outliers. We assessed normality of the subject-specific summary measures for each comet parameter and separately for 
case and control groups by Kolmogorov-Smirnov tests and visual inspection of the 20 quantilequantile plots that were generated. Comet values did not deviate from normality, except for CDM among the early-onset breast cancer and the breast cancer and other malignancy case groups and for tail length among the thyroid case group, even after logarithmic transformation. Analysis of variance (ANOVA) was used to compare means of comet values by various factors, including cell viability in culture (determined by trypan blue dye exclusion), cell shipment method (frozen cells or thawed and cultured before shipment), laboratory first handling the freshly collected blood sample (Frederick, MD or Manassas, VA), storage time, date the cells were scored, age of cases and controls at the time of blood collection, time since first cancer diagnosis to blood collection (cases only), history of radiation treatment for cancer (cases only), gender (thyroid cases only), selected reproductive variables (women only), and history of cancer in first degree relatives.

The association between comet values and cancer risk was evaluated by calculating odds ratios and 95\% confidence intervals based on logistic regression. Comet values for tail length, tail DNA, CDM, and OTM were divided into three categories based on the median and $75^{\text {th }}$ percentile of the respective distribution in the control group. All models were adjusted for age in three categories (40-54, 55-74, and 75 years or older), and potentially confounding factors listed above (i.e. cell viability, calendar time the cells were scored, etc.) were evaluated by comparing comet value odds ratios when each factor was or was not included in the model. We found no meaningful change in the point estimates and therefore did not include any of these factors in the final model. Because there were no male controls, we also analyzed the thyroid group excluding the male cases $(n=9)$. We found no consequential alteration in the point estimates and report the odds ratios with men included. Tests for trend were adjusted for age and based on the underlying continuous variable. All significance tests were two sided and $\alpha$ was set at 0.05 . The Statistical Package for the Social Sciences version 12.0 (SPSS, Inc., Chicago, Il) was used for all analyses. 
The coefficient of variation (CV) was calculated separately for each comet parameter [17] among 5 blinded replicate and 16 blinded repeated samples. The CVs for tail DNA were $11.8 \%$ and $14.8 \%$, for tail length were $7.6 \%$ and $12.4 \%$, for CDM were $2.6 \%$ and $6.8 \%$, for OTM were $11.6 \%$ and $18.9 \%$ among the 5 replicates and 16 repeats, respectively. These CV values are comparable to results from a recent study in which a lymphoblastoid line was assayed by alkaline comet for baseline damage in 16 batches of assays; a CV of 22\% was observed [7]. For a radioimmunoassay commonly used for epidemiological studies, a CV of less than $15 \%$ is considered acceptable [18].

\section{Results}

Individual comet results are presented in Table 1, as are the results of the 5 blinded replicates and the 16 blinded repeats. In Table 2 the arithmetic means and standard errors for the comet parameter tail length are shown by categories of selected demographic and descriptive characteristics. The means and standard errors for the comet parameters tail DNA and OTM by these characteristics were very similar to those for tail length and are not shown. Although the distributions of the CDM geometric means between case and control groups differed from those of the other parameter values (see Figure 1), the CDM values did not differ according to categories of the descriptive characteristics and are also not shown. Nearly all of the cases and controls were white (98.2\%, data not shown) and female (95.9\%). Comet values did not increase or decrease with age at the time of blood collection (Table 2) except for tail length among those with thyroid cancer, however, the means did not differ by age group $(P=0.39)$. Similarly, comet parameters did not differ by the number of years between cancer diagnosis and blood collection (cases only), radiation treatment for cancer (cases only), and selected reproductive variables (data not shown). Tail length tended to marginally increase in most groups as the number of first degree relatives with breast 
cancer and the number of cancers within individuals increased ( 9 persons had three or more cancers, data not shown), but achieved only borderline statistical significance $(P=0.07)$. History of chemotherapy did not affect the means of the comet parameters, but the data obtained from medical records was incomplete (yes, $n=13$; no, $n=16$; unknown, $n=118$ ). The means and standard errors (parentheses) for tail length were 44.8 (1.7), 43.9 (2.8), and 45.0 (0.8) among those who did and did not have chemotherapy or their treatment status was not known, respectively $(P=0.88)$. We did not observe significant differences in comet parameters means for viability, sample shipment method, storage time, original laboratory, or calendar time over which the cells were scored.

Boxplots of the distributions of the geometric means of the comet parameters across 100 cells for each individual by case and control groups are shown in Figure 1. All the parameters, except CDM, tended to be lower in the normal controls than the cancer case groups, with the hypernormal group having the lowest values of all the groups. Most comet parameters were highly correlated with each other $\left(\mathrm{r}^{2} \geq 0.49, P<0.001\right)$. However, CDM was not correlated with tail length among the normal controls, the hyper-normal controls, and the breast and other cancer cases. We present age-adjusted odds ratios (OR) and 95\% confidence intervals (CI) for cancer risk in relationship to comet parameter categories in Table 3, with cancer cases and hyper-normal controls compared to normal controls. As the values of the comet parameters increased, indicating increasing endogenous SSB and alkali labile DNA damage in the cells, the risks for breast and other cancer and thyroid cancer generally also increased. Longer tail length was consistently associated with increased cancer risk, with ORs of $10.1,4.7$, and 19.1 associated with values $\geq 75^{\text {th }}$ percentile vs. below the median for the breast and other cancer, early-onset breast cancer, and thyroid cancer groups, respectively, with wide confidence intervals. Risk for early-onset breast cancer was inversely associated with tail DNA and CDM, and was not related to OTM. The hyper-normal controls were at or below the median of the normal controls for all comet parameters except CDM. 


\section{Discussion}

We found a generally consistent association of increased endogenous DNA damage, or more specifically, a reduced capacity to limit endogenous damage, and increased cancer risk. This association was most strongly indicated by higher values of the comet parameter tail length. Risk of breast and other cancer and thyroid cancer also increased with increased tail DNA and OTM or only OTM, respectively. In addition, we found suggestive evidence in three of the four comet parameters evaluated that lower levels of DNA damage were associated with being long-lived, cancer-free, and without a history of cancer among first degree relatives, supporting the notion of a graded capacity to control endogenous DNA damage. We consider detecting evidence of such a continuum unique because hospital- or clinic-based studies seldom possess a well-characterized cohort from which to select individuals with defined characteristics, such as longevity and first degree relatives who are cancer-free. It is likely the hyper-normal individuals were also relatively free of co-morbidities, as they were able to visit their doctor or clinic with a study venipuncture kit and mail the kit successfully. This suggests the hyper-normal participants were probably the "healthiest" and the best group for detecting such a continuum, if it exists.

Comet tail length showed the strongest positive association with cancer risk among the four DNA damage parameters evaluated. The tail length parameter increases with increased density of abasic sites and strand breaks due to higher mobility of regions of DNA. That tail length was optimal for discriminating among groups suggests that a better understanding of the mechanistic significance of comet parameters and underlying biology is needed. There are few studies comparing multiple comet parameters, and most treat cells with high doses of a damaging agent such as ionizing radiation that induces uniformally distributed damage. It is not known whether the lower response of tail length versus tail moment and tail DNA to damage induced up to 4 Gy [19] is 
an appropriate reference for studies of endogenous damage, that is both quantitatively lower and qualitatively different due to preferential repair in transcribed regions of the genome. Our observations suggest tail length may be a sensitive indicator of low levels of inhomogeneously distributed unrepaired damage. It is appropriate to note, that of the four parameters, tail length is most subject to technical variation. Among all study groups, the three tail-related comet parameters (i.e. tail DNA, tail length, and OTM) were highly correlated. In the control, hypernormal, and breast and another cancer groups, CDM did not correlate with tail length. The correlation differences within study groups in comet parameters may indicate that the distribution of damage throughout the genome (between comet head and tail) is determined by multiple, independent processes, some operating throughout the genome, others not. Studies of the relationships between comet parameters and loss of specific DNA repair functions using cells with defined mutations of DNA repair genes would be useful.

Using post-diagnostic samples for assessing the predictive value of phenotype assays such as the Comet assay is less than ideal because assay outcome may be affected by disease status or treatment [20]. The study should be replicated with pre-diagnostic samples collected in a large prospective study. However, we found little variation in the comet assay outcome with several factors, including age, survival time (among cases), radiation treatment, and reproductive history. This is consistent with other investigations $[7,8,21,22]$. The lymphoblastoid cell lines provided an infinite supply of cycling cells that can be used for additional assays in the future, in which damage levels are expected to reflect endogenous processes of DNA metabolism and are unlikely to reflect occupational, diet or other lifestyle variables. One cannot rule out the possibility that the transformed cells have acquired properties that may affect relevance to normal tissues.

We evaluated several factors that could have affected comet measures in systematic ways, such as cell viability, storage time, etc. We did not find evidence that these factors introduduced 
predictable variation in comet values. However, we did not randomly assay the lines nor did we assess "batch" effects. The closest proxy to "batch" was "cell scoring date", and we did not observe undue systematic variation over calendar time in the aggregate or by case or control groups.

In the future, studies of the level and specific nature of oxidative damage in unchallenged cells (as by Collins and colleagues $[23,24]$ ) would provide valuable knowledge about the variation among individuals, and contribute to development of hypotheses to test. As the environmental risk factors for these cancers are identified in case-control studies of the parent U.S. Radiologic Technologist cohort, challenge assays that measure the formation and repair of damage from exposure to related model mutagens, such as ionizing radiation or BPDE, may be appropriate [3].

Results of the comet assay, performed on un-challenged cells, may represent an individual's capacity to limit endogenous damage and its associated health consequences. This hypothesis is supported by several other studies in which higher background comet assay results were related to increased risk for cancer at different sites [7-9]. A corollary is that being cancer-free at advanced age might be associated with maintaining lower levels of endogenous damage. Analyses of such hyper-normal individuals have been limited generally because laboratory, clinical or hospital studies infrequently have a population base from which to select a hyper-normal group. However, enriching sample selection by various subject attributes may become more common as this design may offer gains in study power (reviewed in [25]). The ability to explore such concepts is a strength of the large U.S. Radiologic Technologist cohort utilized in this study.

In summary, we present results that indicate increased endogenous DNA damage may increase risk for multiple cancers (that include breast cancer) and thyroid cancer. Our conclusions are strengthened by the observation that decreased endogenous DNA damage was suggestively associated with being long-lived, cancer-free, and without a history of cancer in first degree relatives. Together these results indicate a continuum of DNA damage exists and may be detected 
by phenotypic assays. If replicated in a large prospective study, relatively simple functional assays such as this could contribute to identification of persons with increased cancer susceptibility. 


\section{Acknowledgements}

This research was supported in part by contracts NO1-CP-15673, NO1-CP-51016, NO2-CP81005, and NO2-CP-81121 by the National Cancer Institute, the National Institutes of Health, U.S. Public Health Service, Department of Health and Human Services and in part under the auspices of the U.S. Department of Energy by the University of California, Lawrence Livermore National Laboratory under Contract No. W-7405-Eng-48. The authors thank Dr. Thomas R. Fears for helpful advice on the coefficient of variation calculations. We are grateful to the radiologic technologists who participated in this study; Jerry Reid of the American Registry of Radiologic Technologists for continued support of this project; Diane Kampa of the University of Minnesota for overseeing data collection and coordination; Kathy Chimes of Westat, Inc. for data management; and Laura Bowen of Information Management Services, Inc. for biomedical computing. 


\section{References}

[1] D.M. Wilson III, L.H. Thompson, Life without DNA repair. Proc. Natl. Acad. Sci. 94 (1997) 12754-12757.

[2] Lindahl T, Wood R.D, Quality control by DNA repair. Science 286 (1999) 1897-2005.

[3] M. Berwick, P. Vineis, Markers of DNA repair and susceptibility to cancer in humans: an epidemiologic review. J. Natl. Cancer Inst. 92 (2000) 874-897.

[4] E.C. Freidberg, DNA damage and repair, Nature 2003;421:436-440.

[5] M. R. Spitz, Q. Wei, Q. Dong, C.I. Amos, X. Wu, Genetic susceptibility to lung cancer: the role of DNA damage and repair, Cancer Epidemiol. Biomarkers Prev. 12 (2003) 689-698.

[6] P.A. Futreal, L. Coin, M. Marshall, et al., A census of human cancer genes, Nature Rev. Cancer 4 (2004) 177-183.

[7] T.R. Smith, M.S. Miller, K.K. Lohman, L.D. Case, J.J. Hu, DNA damage and breast cancer risk. Carcinogenesis 24 (2003) 883-889.

[8] S. Colleu-Durel, N Guitton N, Nourgalieva K, et al., Alkaline single-cell gel electrophoresis (comet assay): a simple technique to show genomic instability in sporadic breast cancer, Eur. J. Cancer 40 (2004) 445-451.

[9] M.B. Schabath, M.R. Spitz, H.B. Grossman, et al., Genetic instability in bladder cancer assessed by the comet assay, J. Natl. Cancer Inst. 95 (2003) 540-547.

[10] N.P. Singh, M.T. McCoy, R.R. Tice, E.L. Schneider, A simple technique for quantitation of low levels of DNA damage in individual cells, Exp. Cell Res. 175 (1988) 184-191. 
[11] T. Lindahl, Suppression of spontaneous mutagenesis in human cells by DNA base excision-repair, Mutation Res. 462 (2000) 129-135.

[12] L.J. Marnett, J.P. Plastaras, Endogenous DNA damage and mutation, Trends Genet. 17 (2001) 214221.

[13] R. de Bont, N. van Larebeke, Endogenous DNA damage in humans: a review of quantitative damage, Mutagenesis 19 (2004) 169-185.

[14] A.J. Sigurdson, M.M. Doody, R.S. Rao, et al., Cancer Incidence in the U. S. Radiologic Technologists Health Study, 1984-1998, Cancer 97 (2003) 3080-3089.

[15] J.D. Boice Jr., C.E. Land, D.L. Preston. Ionizing radiation, in: D. Schottenfeld and J.F. Fraumeni, Jr. (Eds.), Cancer Epidemiology and Prevention, $2^{\text {nd }}$ Ed., Oxford University Press, New York, 1996, pp. 319-354.

[16] N.E. Morton, A. Collins, Tests and estimates of allelic association in complex inheritance, Proc. Natl. Acad. Sci. 95 (1998) 11389-11393.

[17] G.W. Snedecor, W.G. Cochran WG, Statistical Methods, 6th Ed. 1967, pp. 294-296.

[18] R.T. Falk, M.H. Gail, T.R. Fears, et al., Reproducibility and validity of radioimmunoassay for urinary hormones and metabolites in pre-and postmenopausal women, Cancer Epidemiol. Biomarkers Prev. 8 (1999) 567-577.

[19] G.A. Haines, J.H. Hendry, C.P. Daniel, I.D. Morris, Germ cell and dose-dependent DNA damage measured by the comet assay in murine spermatozoa after testicular X-irradiation. Biol. Reproduction 67 (2002) 854-861.

[20] A. Collins, V. Harrington, Repair of oxidative DNA damage: assessing its contribution to cancer prevention, Mutagenesis 17 (2002) 489-493. 
[21] P. Møller, L.E. Knudsen, S. Loft, H. Wallin, The comet assay as a rapid test in biomonitoring occupational exposure to DNA-damaging agents and confounding factors, Cancer Epidemiol. Biomarkers Prev. 9 (2000) 1005-1015.

[22] K. Baria, C. Warren, S.A. Roberts, C.M. West, D. Scott, Chromosomal radiosensitivity as a marker of predisposition to common cancers? Br. J. Cancer 84 (2001) 892-896.

[23] A.R. Collins, S.J. Duthie, V.L. Dobson, Direct enzymatic detection of endogenous base damage in human lymphocyte DNA. Exp. Cell Res. 164 (1993) 1733-1735.

[24] A.R. Collins, M. Dusinka, C.M. Gedik, R. Stetina, Oxidative damage to DNA: Do we have a reliable biomarker? Environ. Health Perspect. 104 (1996) 465-469.

[25] P.D.P Pharoah, A.M. Dunning, B.A.J. Ponder, D.F. Easton, Association studies for finding cancersusceptibility genetic variants, Nature Rev. Cancer 4 (2004) 850-860. 
Table 1. Comet data for each subject in the control and case groups by ascending values of tail length and quality control result values for the blinded replicates and blinded repeats.

\begin{tabular}{|c|c|c|c|c|c|c|c|}
\hline $\begin{array}{c}\text { ID } \\
\text { number }\end{array}$ & Gender & $\begin{array}{l}\text { Age at time } \\
\text { of blood draw }\end{array}$ & $\begin{array}{c}\text { Tail } \\
\text { length }\end{array}$ & Tail DNA & $\begin{array}{r}\text { Comet } \\
\text { Distributed } \\
\text { Moment }\end{array}$ & $\begin{array}{r}\text { Olive } \\
\text { Tail } \\
\text { Moment }\end{array}$ & Group* \\
\hline 144 & $\mathrm{~F}$ & 45 & 15.4 & 6.7 & 17.6 & 1.5 & Control \\
\hline 273 & $\mathrm{~F}$ & 57 & 17.7 & 6.1 & 17.9 & 1.4 & Control \\
\hline 29 & $\mathrm{~F}$ & 43 & 17.8 & 11.9 & 20.8 & 3.5 & Control \\
\hline 25 & $\mathrm{~F}$ & 60 & 17.9 & 6.6 & 18.5 & 1.6 & Control \\
\hline 129 & $\mathrm{~F}$ & 60 & 23.1 & 6.9 & 19.4 & 1.8 & Control \\
\hline 110 & $\mathrm{~F}$ & 66 & 23.5 & 6.4 & 17.1 & 1.4 & Control \\
\hline 132 & $\mathrm{~F}$ & 74 & 23.9 & 7.6 & 19.0 & 1.7 & Control \\
\hline 74 & $\mathrm{~F}$ & 53 & 24.2 & 10.1 & 19.9 & 2.6 & Control \\
\hline 261 & $\mathrm{~F}$ & 42 & 24.3 & 7.7 & 18.1 & 1.7 & Control \\
\hline 216 & $\mathrm{~F}$ & 76 & 26.3 & 8.4 & 22.0 & 2.2 & Control \\
\hline 15 & $\mathrm{~F}$ & 42 & 27.5 & 10.4 & 20.6 & 2.7 & Control \\
\hline 43 & $\mathrm{~F}$ & 69 & 27.7 & 10.0 & 20.8 & 2.7 & Control \\
\hline 16 & $\mathrm{~F}$ & 53 & 27.7 & 8.5 & 18.0 & 2.2 & Control \\
\hline 134 & $\mathrm{~F}$ & 90 & 27.9 & 9.3 & 19.8 & 2.1 & Control \\
\hline 81 & $\mathrm{~F}$ & 53 & 28.0 & 6.3 & 18.5 & 1.8 & Control \\
\hline 34 & $\mathrm{~F}$ & 82 & 28.3 & 7.7 & 20.5 & 2.1 & Control \\
\hline 213 & $\mathrm{~F}$ & 48 & 29.3 & 9.8 & 19.9 & 2.2 & Control \\
\hline 35 & $\mathrm{~F}$ & 81 & 31.5 & 10.0 & 19.9 & 2.6 & Control \\
\hline 249 & $\mathrm{~F}$ & 71 & 31.6 & 8.7 & 19.1 & 2.1 & Control \\
\hline 79 & $\mathrm{~F}$ & 51 & 32.3 & 9.0 & 16.2 & 1.9 & Control \\
\hline 235 & $\mathrm{~F}$ & 62 & 32.6 & 9.6 & 20.3 & 2.3 & Control \\
\hline 233 & $\mathrm{~F}$ & 65 & 33.0 & 10.3 & 22.7 & 2.8 & Control \\
\hline 88 & $\mathrm{~F}$ & 50 & 33.1 & 9.9 & 18.8 & 2.5 & Control \\
\hline 68 & $\mathrm{~F}$ & 61 & 33.3 & 9.2 & 19.5 & 2.4 & Control \\
\hline 154 & $\mathrm{~F}$ & 43 & 33.3 & 12.6 & 20.8 & 3.2 & Control \\
\hline 101 & $\mathrm{~F}$ & 68 & 33.6 & 7.7 & 20.5 & 2.1 & Control \\
\hline 165 & $\mathrm{~F}$ & 83 & 34.3 & 9.5 & 20.5 & 2.6 & Control \\
\hline 195 & $\mathrm{~F}$ & 71 & 34.5 & 8.3 & 21.3 & 2.3 & Control \\
\hline 24 & $\mathrm{~F}$ & 86 & 36.0 & 6.9 & 17.4 & 1.7 & Control \\
\hline 92 & $\mathrm{~F}$ & 74 & 36.2 & 10.0 & 19.5 & 2.4 & Control \\
\hline 223 & $\mathrm{~F}$ & 82 & 36.6 & 8.7 & 18.1 & 2.1 & Control \\
\hline 50 & $\mathrm{~F}$ & 46 & 37.0 & 10.5 & 17.6 & 2.4 & Control \\
\hline 136 & $\mathrm{~F}$ & 79 & 37.6 & 9.4 & 18.6 & 2.2 & Control \\
\hline 151 & $\mathrm{~F}$ & 71 & 38.6 & 11.2 & 21.3 & 3.0 & Control \\
\hline 240 & $\mathrm{~F}$ & 51 & 39.6 & 9.5 & 17.7 & 2.5 & Control \\
\hline 214 & $\mathrm{~F}$ & 61 & 41.9 & 11.7 & 23.0 & 3.0 & Control \\
\hline 118 & $\mathrm{~F}$ & 64 & 43.3 & 12.4 & 19.7 & 3.1 & Control \\
\hline 3 & $\mathrm{~F}$ & 46 & 45.4 & 9.9 & 18.7 & 2.5 & Control \\
\hline 172 & $\mathrm{~F}$ & 50 & 47.3 & 10.7 & 19.2 & 2.9 & Control \\
\hline 231 & $\mathrm{~F}$ & 71 & 47.3 & 11.8 & 18.9 & 2.8 & Control \\
\hline 126 & $\mathrm{~F}$ & 54 & 47.5 & 11.0 & 19.8 & 2.8 & Control \\
\hline 52 & $\mathrm{~F}$ & 84 & 48.5 & 9.6 & 19.5 & 2.5 & Control \\
\hline 113 & $\mathrm{~F}$ & 49 & 49.3 & 10.8 & 19.3 & 2.7 & Control \\
\hline 38 & $\mathrm{~F}$ & 64 & 49.4 & 9.9 & 20.1 & 2.6 & Control \\
\hline 212 & $\mathrm{~F}$ & 68 & 49.9 & 12.1 & 21.1 & 3.1 & Control \\
\hline
\end{tabular}




\begin{tabular}{|c|c|c|c|c|c|c|c|}
\hline 95 & $\mathrm{~F}$ & 74 & 50.1 & 9.3 & 18.8 & 2.5 & Control \\
\hline 104 & $\mathrm{~F}$ & 46 & 50.8 & 15.9 & 23.5 & 4.4 & Control \\
\hline 178 & $\mathrm{~F}$ & 65 & 53.7 & 10.0 & 18.6 & 2.6 & Control \\
\hline 44 & $\mathrm{~F}$ & 63 & 56.8 & 13.4 & 20.4 & 3.5 & Control \\
\hline 148 & $\mathrm{~F}$ & 89 & 10.2 & 5.9 & 17.8 & 1.3 & H-Normal \\
\hline 255 & $\mathrm{~F}$ & 72 & 12.4 & 8.3 & 21.1 & 2.3 & H-Normal \\
\hline 122 & $\mathrm{~F}$ & 77 & 19.9 & 6.1 & 18.4 & 1.5 & H-Normal \\
\hline 185 & $\mathrm{~F}$ & 89 & 21.3 & 8.4 & 22.2 & 2.4 & H-Normal \\
\hline 269 & $\mathrm{~F}$ & 78 & 21.6 & 6.2 & 20.1 & 1.5 & H-Normal \\
\hline 67 & $\mathrm{~F}$ & 71 & 26.4 & 8.5 & 21.2 & 2.3 & H-Normal \\
\hline 2 & $\mathrm{~F}$ & 70 & 26.5 & 6.3 & 17.4 & 1.4 & H-Normal \\
\hline 141 & $\mathrm{~F}$ & 78 & 26.8 & 10.3 & 21.5 & 2.5 & H-Normal \\
\hline 215 & $\mathrm{~F}$ & 72 & 28.1 & 7.6 & 18.8 & 1.9 & H-Normal \\
\hline 133 & $\mathrm{~F}$ & 70 & 28.4 & 8.1 & 20.8 & 2.1 & H-Normal \\
\hline 45 & $\mathrm{~F}$ & 75 & 30.9 & 7.4 & 17.6 & 1.8 & H-Normal \\
\hline 149 & $\mathrm{~F}$ & 70 & 31.1 & 8.1 & 18.4 & 1.9 & H-Normal \\
\hline 251 & $\mathrm{~F}$ & 71 & 31.5 & 9.4 & 22.9 & 2.4 & H-Normal \\
\hline 150 & $\mathrm{~F}$ & 85 & 31.6 & 6.4 & 17.6 & 1.6 & H-Normal \\
\hline 245 & $\mathrm{~F}$ & 73 & 32.0 & 8.0 & 21.9 & 2.0 & H-Normal \\
\hline 180 & $\mathrm{~F}$ & 81 & 33.5 & 6.8 & 17.0 & 1.5 & H-Normal \\
\hline 202 & $\mathrm{~F}$ & 74 & 35.6 & 8.5 & 21.2 & 2.1 & H-Normal \\
\hline 107 & $\mathrm{~F}$ & 70 & 40.1 & 12.3 & 22.8 & 3.1 & H-Normal \\
\hline 219 & $\mathrm{~F}$ & 80 & 51.2 & 11.5 & 20.4 & 3.0 & H-Normal \\
\hline 119 & $\mathrm{~F}$ & 79 & 51.9 & 9.3 & 18.7 & 2.4 & H-Normal \\
\hline 112 & $\mathrm{~F}$ & 67 & 18.7 & 6.3 & 19.5 & 1.6 & Breast Plus \\
\hline 226 & $\mathrm{~F}$ & 70 & 27.4 & 11.0 & 25.9 & 3.0 & Breast Plus \\
\hline 194 & $\mathrm{~F}$ & 76 & 29.2 & 8.0 & 20.5 & 2.0 & Breast Plus \\
\hline 32 & $\mathrm{~F}$ & 83 & 29.5 & 8.0 & 18.6 & 2.1 & Breast Plus \\
\hline 250 & $\mathrm{~F}$ & 67 & 29.8 & 9.3 & 21.7 & 2.3 & Breast Plus \\
\hline 55 & $\mathrm{~F}$ & 80 & 34.1 & 10.0 & 22.6 & 2.6 & Breast Plus \\
\hline 218 & $\mathrm{~F}$ & 57 & 34.9 & 9.2 & 18.2 & 2.4 & Breast Plus \\
\hline 127 & $\mathrm{~F}$ & 63 & 35.2 & 9.1 & 19.9 & 2.1 & Breast Plus \\
\hline 140 & $\mathrm{~F}$ & 70 & 35.5 & 10.6 & 22.7 & 2.8 & Breast Plus \\
\hline 63 & $\mathrm{~F}$ & 76 & 37.4 & 9.0 & 20.7 & 2.3 & Breast Plus \\
\hline 152 & $\mathrm{~F}$ & 63 & 38.0 & 10.8 & 19.5 & 2.8 & Breast Plus \\
\hline 210 & $\mathrm{~F}$ & 59 & 38.4 & 8.8 & 20.4 & 2.3 & Breast Plus \\
\hline 143 & $\mathrm{~F}$ & 76 & 39.3 & 8.7 & 21.2 & 2.3 & Breast Plus \\
\hline 222 & $\mathrm{~F}$ & 82 & 41.2 & 9.1 & 20.5 & 2.4 & Breast Plus \\
\hline 49 & $\mathrm{~F}$ & 49 & 41.2 & 13.8 & 25.5 & 3.6 & Breast Plus \\
\hline 196 & $\mathrm{~F}$ & 48 & 41.7 & 8.3 & 18.5 & 2.2 & Breast Plus \\
\hline 70 & $\mathrm{~F}$ & 82 & 43.1 & 9.1 & 20.0 & 2.6 & Breast Plus \\
\hline 211 & $\mathrm{~F}$ & 43 & 43.1 & 10.8 & 20.0 & 2.9 & Breast Plus \\
\hline 183 & $\mathrm{~F}$ & 69 & 44.4 & 10.2 & 18.4 & 2.4 & Breast Plus \\
\hline 182 & $\mathrm{~F}$ & 75 & 44.6 & 10.4 & 19.2 & 2.6 & Breast Plus \\
\hline 189 & $\mathrm{~F}$ & 45 & 44.6 & 9.7 & 19.9 & 2.6 & Breast Plus \\
\hline 26 & $\mathrm{~F}$ & 76 & 45.2 & 13.0 & 25.6 & 3.9 & Breast Plus \\
\hline 174 & $\mathrm{~F}$ & 47 & 46.4 & 10.9 & 19.2 & 2.9 & Breast Plus \\
\hline 203 & $\mathrm{~F}$ & 62 & 47.2 & 9.4 & 19.3 & 2.4 & Breast Plus \\
\hline 197 & $\mathrm{~F}$ & 59 & 47.7 & 11.3 & 20.8 & 3.0 & Breast Plus \\
\hline 65 & $\mathrm{~F}$ & 84 & 48.0 & 11.9 & 20.1 & 3.2 & Breast Plus \\
\hline 130 & $\mathrm{~F}$ & 77 & 48.3 & 9.8 & 19.1 & 2.5 & Breast Plus \\
\hline
\end{tabular}




\begin{tabular}{|c|c|c|c|c|c|c|c|}
\hline 114 & $\mathrm{~F}$ & 65 & 48.8 & 11.1 & 20.0 & 2.9 & Breast Plus \\
\hline 84 & $\mathrm{~F}$ & 63 & 49.6 & 9.6 & 20.5 & 2.7 & Breast Plus \\
\hline 187 & $\mathrm{~F}$ & 57 & 50.1 & 9.6 & 21.3 & 2.6 & Breast Plus \\
\hline 40 & $\mathrm{~F}$ & 64 & 50.2 & 11.2 & 20.3 & 2.9 & Breast Plus \\
\hline 125 & $\mathrm{~F}$ & 62 & 50.5 & 12.3 & 20.4 & 3.1 & Breast Plus \\
\hline 206 & $\mathrm{~F}$ & 72 & 51.2 & 10.3 & 18.9 & 2.7 & Breast Plus \\
\hline 60 & $\mathrm{~F}$ & 90 & 52.0 & 10.6 & 20.7 & 2.9 & Breast Plus \\
\hline 80 & $\mathrm{~F}$ & 74 & 52.3 & 13.7 & 23.3 & 3.8 & Breast Plus \\
\hline 53 & $\mathrm{~F}$ & 65 & 52.5 & 10.1 & 19.6 & 2.7 & Breast Plus \\
\hline 236 & $\mathrm{~F}$ & 58 & 52.9 & 9.7 & 18.9 & 2.7 & Breast Plus \\
\hline 21 & $\mathrm{~F}$ & 49 & 53.0 & 9.1 & 19.4 & 2.5 & Breast Plus \\
\hline 76 & $\mathrm{~F}$ & 48 & 56.9 & 12.5 & 21.3 & 3.4 & Breast Plus \\
\hline 262 & $\mathrm{~F}$ & 65 & 57.4 & 13.1 & 20.8 & 3.4 & Breast Plus \\
\hline 94 & $\mathrm{~F}$ & 70 & 57.7 & 12.8 & 22.1 & 3.7 & Breast Plus \\
\hline 171 & $\mathrm{~F}$ & 65 & 64.8 & 8.6 & 19.1 & 2.3 & Breast Plus \\
\hline 167 & $\mathrm{~F}$ & 48 & 28.8 & 7.5 & 17.8 & 1.8 & Early onset \\
\hline 10 & $\mathrm{~F}$ & 59 & 28.9 & 8.0 & 17.9 & 2.1 & Early onset \\
\hline 14 & $\mathrm{~F}$ & 67 & 31.1 & 7.3 & 18.9 & 1.8 & Early onset \\
\hline 71 & $\mathrm{~F}$ & 51 & 31.2 & 9.8 & 20.0 & 2.7 & Early onset \\
\hline 153 & $\mathrm{~F}$ & 58 & 31.9 & 8.9 & 18.3 & 2.4 & Early onset \\
\hline 166 & $\mathrm{~F}$ & 44 & 32.9 & 7.6 & 18.2 & 2.0 & Early onset \\
\hline 77 & $\mathrm{~F}$ & 64 & 33.1 & 8.3 & 18.2 & 2.1 & Early onset \\
\hline 266 & $\mathrm{~F}$ & 50 & 33.5 & 8.2 & 18.6 & 2.3 & Early onset \\
\hline 164 & $\mathrm{~F}$ & 62 & 33.8 & 8.1 & 18.5 & 2.1 & Early onset \\
\hline 177 & $\mathrm{~F}$ & 45 & 34.5 & 8.1 & 18.8 & 2.0 & Early onset \\
\hline 200 & $\mathrm{~F}$ & 49 & 34.7 & 8.9 & 18.2 & 2.3 & Early onset \\
\hline 234 & $\mathrm{~F}$ & 50 & 35.2 & 10.4 & 18.1 & 2.5 & Early onset \\
\hline 83 & $\mathrm{~F}$ & 47 & 37.2 & 7.4 & 16.8 & 1.9 & Early onset \\
\hline 111 & $\mathrm{~F}$ & 51 & 38.1 & 10.6 & 18.8 & 2.5 & Early onset \\
\hline 28 & $\mathrm{~F}$ & 42 & 39.7 & 8.7 & 18.8 & 2.3 & Early onset \\
\hline 82 & $\mathrm{~F}$ & 45 & 40.1 & 9.8 & 18.2 & 2.4 & Early onset \\
\hline 274 & $\mathrm{~F}$ & 57 & 40.5 & 9.2 & 18.5 & 2.3 & Early onset \\
\hline 208 & $\mathrm{~F}$ & 51 & 41.0 & 10.1 & 18.8 & 2.5 & Early onset \\
\hline 254 & $\mathrm{~F}$ & 48 & 41.8 & 10.6 & 20.2 & 2.7 & Early onset \\
\hline 158 & $\mathrm{~F}$ & 55 & 42.9 & 9.4 & 18.6 & 2.5 & Early onset \\
\hline 169 & $\mathrm{~F}$ & 45 & 44.5 & 9.3 & 20.0 & 2.7 & Early onset \\
\hline 9 & $\mathrm{~F}$ & 56 & 45.2 & 9.4 & 18.9 & 2.3 & Early onset \\
\hline 237 & $\mathrm{~F}$ & 49 & 45.8 & 10.2 & 18.9 & 2.5 & Early onset \\
\hline 175 & $\mathrm{~F}$ & 46 & 47.1 & 10.8 & 19.2 & 2.8 & Early onset \\
\hline 173 & $\mathrm{~F}$ & 70 & 48.4 & 9.9 & 18.6 & 2.7 & Early onset \\
\hline 207 & $\mathrm{~F}$ & 47 & 48.7 & 9.3 & 18.5 & 2.4 & Early onset \\
\hline 252 & $\mathrm{~F}$ & 60 & 48.8 & 10.1 & 18.7 & 2.6 & Early onset \\
\hline 163 & $\mathrm{~F}$ & 59 & 49.2 & 9.9 & 18.5 & 2.7 & Early onset \\
\hline 8 & $\mathrm{~F}$ & 49 & 50.4 & 10.0 & 19.4 & 2.9 & Early onset \\
\hline 157 & $\mathrm{~F}$ & 45 & 50.6 & 9.1 & 19.4 & 2.5 & Early onset \\
\hline 267 & $\mathrm{~F}$ & 55 & 50.7 & 11.9 & 20.7 & 3.3 & Early onset \\
\hline 103 & $\mathrm{~F}$ & 48 & 50.9 & 12.8 & 21.3 & 3.3 & Early onset \\
\hline 264 & $\mathrm{~F}$ & 59 & 51.8 & 10.2 & 20.2 & 2.9 & Early onset \\
\hline 135 & $\mathrm{~F}$ & 50 & 52.7 & 9.7 & 18.8 & 2.5 & Early onset \\
\hline 191 & F & 67 & 53.3 & 9.5 & 23.0 & 2.8 & Early onset \\
\hline 147 & $\mathrm{~F}$ & 44 & 54.9 & 9.8 & 21.0 & 2.8 & Early onset \\
\hline
\end{tabular}




\begin{tabular}{|c|c|c|c|c|c|c|c|}
\hline 6 & $\mathrm{~F}$ & 46 & 55.9 & 10.2 & 19.7 & 2.8 & Early onset \\
\hline 108 & $\mathrm{~F}$ & 53 & 56.7 & 13.1 & 20.4 & 3.5 & Early onset \\
\hline 51 & $\mathrm{~F}$ & 53 & 26.8 & 7.6 & 18.0 & 1.8 & Thyroid \\
\hline 75 & $\mathrm{~F}$ & 42 & 29.9 & 7.0 & 16.2 & 1.4 & Thyroid \\
\hline 46 & $\mathrm{~F}$ & 53 & 30.7 & 7.2 & 17.9 & 1.7 & Thyroid \\
\hline 256 & $\mathrm{~F}$ & 49 & 32.9 & 7.7 & 18.0 & 2.0 & Thyroid \\
\hline 272 & $\mathrm{~F}$ & 48 & 33.1 & 8.0 & 17.6 & 1.7 & Thyroid \\
\hline 105 & $\mathrm{~F}$ & 54 & 33.2 & 6.9 & 17.7 & 1.6 & Thyroid \\
\hline 17 & $\mathrm{~F}$ & 63 & 34.1 & 8.7 & 18.7 & 2.4 & Thyroid \\
\hline 271 & $\mathrm{~F}$ & 52 & 34.5 & 8.6 & 19.6 & 2.0 & Thyroid \\
\hline 225 & M & 57 & 34.7 & 8.8 & 18.8 & 2.1 & Thyroid \\
\hline 176 & $\mathrm{~F}$ & 48 & 35.1 & 7.0 & 18.2 & 1.7 & Thyroid \\
\hline 109 & $\mathrm{~F}$ & 56 & 36.9 & 7.6 & 17.1 & 1.8 & Thyroid \\
\hline 61 & $\mathrm{~F}$ & 42 & 37.2 & 6.9 & 18.1 & 1.6 & Thyroid \\
\hline 263 & $\mathrm{~F}$ & 54 & 38.7 & 7.8 & 18.7 & 1.9 & Thyroid \\
\hline 42 & F & 41 & 39.6 & 8.6 & 18.9 & 2.3 & Thyroid \\
\hline 217 & $\mathrm{~F}$ & 66 & 39.8 & 8.9 & 19.0 & 2.3 & Thyroid \\
\hline 85 & $\mathrm{~F}$ & 58 & 39.8 & 7.7 & 18.4 & 2.1 & Thyroid \\
\hline 209 & $\mathrm{~F}$ & 56 & 40.2 & 8.4 & 18.5 & 2.0 & Thyroid \\
\hline 72 & $\mathrm{~F}$ & 49 & 40.3 & 9.0 & 19.5 & 2.2 & Thyroid \\
\hline 162 & $\mathrm{~F}$ & 61 & 40.8 & 7.3 & 18.5 & 2.2 & Thyroid \\
\hline 159 & M & 44 & 42.3 & 9.1 & 19.8 & 2.5 & Thyroid \\
\hline 247 & M & 71 & 43.8 & 11.4 & 21.1 & 3.1 & Thyroid \\
\hline 7 & $\mathrm{~F}$ & 66 & 45.2 & 10.7 & 20.2 & 3.0 & Thyroid \\
\hline 33 & $\mathrm{~F}$ & 53 & 45.4 & 9.4 & 17.8 & 2.3 & Thyroid \\
\hline 23 & $\mathrm{~F}$ & 53 & 45.7 & 12.2 & 21.0 & 3.1 & Thyroid \\
\hline 87 & F & 63 & 45.7 & 10.8 & 19.1 & 2.8 & Thyroid \\
\hline 19 & $\mathrm{~F}$ & 48 & 46.4 & 12.0 & 20.5 & 3.3 & Thyroid \\
\hline 224 & $\mathrm{~F}$ & 44 & 46.7 & 10.1 & 19.6 & 2.8 & Thyroid \\
\hline 78 & $\mathrm{~F}$ & 63 & 47.0 & 11.3 & 20.6 & 2.9 & Thyroid \\
\hline 181 & $\mathrm{~F}$ & 46 & 47.0 & 11.0 & 21.9 & 2.9 & Thyroid \\
\hline 259 & F & 51 & 47.4 & 10.1 & 19.3 & 2.7 & Thyroid \\
\hline 260 & $\mathrm{~F}$ & 71 & 47.5 & 10.8 & 20.1 & 2.8 & Thyroid \\
\hline 241 & $\mathrm{~F}$ & 74 & 47.6 & 10.8 & 21.5 & 2.9 & Thyroid \\
\hline 270 & $\mathrm{~F}$ & 54 & 47.7 & 9.8 & 20.4 & 2.6 & Thyroid \\
\hline 275 & $\mathrm{~F}$ & 74 & 48.0 & 11.8 & 17.8 & 2.9 & Thyroid \\
\hline 193 & $\mathrm{~F}$ & 49 & 48.5 & 8.4 & 17.3 & 2.1 & Thyroid \\
\hline 1 & F & 60 & 48.7 & 10.2 & 19.0 & 2.6 & Thyroid \\
\hline 98 & $\mathrm{~F}$ & 48 & 49.3 & 9.7 & 19.5 & 2.6 & Thyroid \\
\hline 131 & $\mathrm{~F}$ & 55 & 49.4 & 9.2 & 19.2 & 2.6 & Thyroid \\
\hline 246 & $\mathrm{~F}$ & 66 & 49.4 & 11.1 & 20.0 & 2.8 & Thyroid \\
\hline 117 & $\mathrm{~F}$ & 90 & 49.7 & 10.4 & 21.5 & 2.8 & Thyroid \\
\hline 160 & $\mathrm{~F}$ & 62 & 50.2 & 9.7 & 18.3 & 2.4 & Thyroid \\
\hline 186 & $\mathrm{~F}$ & 51 & 50.2 & 9.7 & 18.3 & 2.4 & Thyroid \\
\hline 99 & F & 70 & 51.3 & 9.8 & 20.0 & 2.6 & Thyroid \\
\hline 248 & $\mathrm{~F}$ & 58 & 51.5 & 9.5 & 20.2 & 2.7 & Thyroid \\
\hline 161 & $\mathrm{~F}$ & 68 & 51.7 & 12.7 & 20.7 & 3.2 & Thyroid \\
\hline 137 & $\mathrm{~F}$ & 57 & 51.9 & 9.7 & 19.2 & 2.6 & Thyroid \\
\hline 239 & $\mathrm{~F}$ & 45 & 52.0 & 8.6 & 21.2 & 2.5 & Thyroid \\
\hline 242 & $\mathrm{~F}$ & 65 & 52.0 & 9.6 & 20.3 & 2.6 & Thyroid \\
\hline 229 & $\mathrm{~F}$ & 53 & 52.3 & 11.2 & 20.0 & 3.0 & Thyroid \\
\hline
\end{tabular}




\begin{tabular}{|c|c|c|c|c|c|c|c|}
\hline 22 & $\mathrm{~F}$ & 45 & 52.4 & 9.1 & 19.1 & 2.6 & Thyroid \\
\hline 86 & F & 45 & 52.4 & 9.0 & 20.4 & 2.5 & Thyroid \\
\hline 258 & $\mathrm{~F}$ & 54 & 52.6 & 10.8 & 21.5 & 3.1 & Thyroid \\
\hline 18 & M & 47 & 53.0 & 11.0 & 21.4 & 3.0 & Thyroid \\
\hline 11 & $\mathrm{~F}$ & 55 & 53.2 & 12.0 & 21.7 & 3.4 & Thyroid \\
\hline 227 & $\mathrm{~F}$ & 56 & 53.2 & 11.6 & 20.6 & 3.0 & Thyroid \\
\hline 253 & M & 56 & 53.4 & 9.8 & 20.9 & 2.8 & Thyroid \\
\hline 27 & $\mathrm{~F}$ & 52 & 53.7 & 9.1 & 18.7 & 2.5 & Thyroid \\
\hline 13 & M & 82 & 53.8 & 11.4 & 20.4 & 2.8 & Thyroid \\
\hline 64 & $\mathrm{~F}$ & 43 & 53.9 & 11.9 & 22.0 & 3.4 & Thyroid \\
\hline 31 & $\mathrm{~F}$ & 78 & 54.2 & 12.1 & 22.1 & 3.2 & Thyroid \\
\hline 48 & $\mathrm{~F}$ & 69 & 54.4 & 9.8 & 18.2 & 2.6 & Thyroid \\
\hline 12 & M & 66 & 54.7 & 11.0 & 19.9 & 2.9 & Thyroid \\
\hline 73 & $\mathrm{~F}$ & 60 & 55.4 & 11.7 & 20.0 & 3.0 & Thyroid \\
\hline 37 & M & 51 & 55.7 & 11.0 & 19.0 & 2.8 & Thyroid \\
\hline 220 & $\mathrm{~F}$ & 54 & 56.3 & 12.9 & 20.3 & 3.2 & Thyroid \\
\hline 30 & $\mathrm{~F}$ & 54 & 56.7 & 10.4 & 20.5 & 2.9 & Thyroid \\
\hline 66 & M & 69 & 60.5 & 10.5 & 20.2 & 2.9 & Thyroid \\
\hline 41 & $\mathrm{~F}$ & 50 & 61.7 & 14.5 & 20.4 & 3.7 & Thyroid \\
\hline A1 & - & - & 32.9 & 7.7 & 18.0 & 2.0 & Replicate \\
\hline A1 & - & - & 37.6 & 9.1 & 19.3 & 2.4 & Replicate \\
\hline B2 & - & - & 40.2 & 8.4 & 18.5 & 2.0 & Replicate \\
\hline B2 & - & - & 51.8 & 14.7 & 21.3 & 3.8 & Replicate \\
\hline C3 & - & - & 46.9 & 8.2 & 18.9 & 2.2 & Replicate \\
\hline C3 & - & - & 51.2 & 12.2 & 19.3 & 3.0 & Replicate \\
\hline D4 & - & - & 52.1 & 10.3 & 19.3 & 2.7 & Replicate \\
\hline D4 & - & - & 56.8 & 10.6 & 19.5 & 2.8 & Replicate \\
\hline E5 & - & - & 51.3 & 9.8 & 20.0 & 2.6 & Replicate \\
\hline E5 & - & - & 41.6 & 9.5 & 19.7 & 2.5 & Replicate \\
\hline R1 & - & - & 41.0 & 10.1 & 18.8 & 2.5 & Repeat \\
\hline R1 & - & - & 37.7 & 8.1 & 17.6 & 1.9 & Repeat \\
\hline $\mathrm{R} 2$ & - & - & 43.6 & 9.8 & 18.2 & 2.4 & Repeat \\
\hline R2 & - & - & 42.3 & 8.7 & 17.9 & 2.0 & Repeat \\
\hline R3 & - & - & 39.8 & 8.1 & 18.5 & 2.1 & Repeat \\
\hline R3 & - & - & 31.8 & 6.9 & 17.0 & 1.6 & Repeat \\
\hline $\mathrm{R} 4$ & - & - & 41.8 & 10.6 & 20.2 & 2.8 & Repeat \\
\hline R4 & - & - & 32.6 & 8.9 & 17.8 & 2.0 & Repeat \\
\hline R5 & - & - & 39.3 & 9.2 & 19.5 & 2.4 & Repeat \\
\hline R5 & - & - & 40.9 & 9.9 & 19.1 & 2.4 & Repeat \\
\hline R6 & - & - & 36.0 & 9.9 & 18.8 & 2.5 & Repeat \\
\hline R6 & - & - & 44.8 & 8.3 & 17.8 & 2.1 & Repeat \\
\hline R7 & - & - & 34.2 & 10.0 & 22.6 & 2.6 & Repeat \\
\hline R7 & - & - & 26.6 & 6.0 & 16.0 & 1.3 & Repeat \\
\hline R8 & - & - & 29.6 & 8.0 & 18.6 & 2.1 & Repeat \\
\hline $\mathrm{R} 8$ & - & - & 30.8 & 6.2 & 16.4 & 1.5 & Repeat \\
\hline R9 & - & - & 36.0 & 9.3 & 20.0 & 2.1 & Repeat \\
\hline R9 & - & - & 27.7 & 5.0 & 17.0 & 1.3 & Repeat \\
\hline R10 & - & - & 46.9 & 9.1 & 20.0 & 2.6 & Repeat \\
\hline $\mathrm{R} 10$ & - & - & 46.9 & 7.8 & 17.4 & 1.9 & Repeat \\
\hline R11 & - & - & 52.0 & 10.6 & 20.7 & 2.9 & Repeat \\
\hline R11 & - & - & 29.0 & 5.3 & 16.0 & 1.2 & Repeat \\
\hline
\end{tabular}




\begin{tabular}{llllrlll} 
R12 & - & - & 49.6 & 9.6 & 20.5 & 2.7 & Repeat \\
R12 & - & - & 31.1 & 6.1 & 16.0 & 1.4 & Repeat \\
R13 & - & - & 50.5 & 12.3 & 20.4 & 3.1 & Repeat \\
R13 & - & - & 29.9 & 5.1 & 16.0 & 1.2 & Repeat \\
R14 & - & - & 51.9 & 10.8 & 21.5 & 2.9 & Repeat \\
R14 & - & - & 36.5 & 9.2 & 18.9 & 2.4 & Repeat \\
R15 & - & - & 51.5 & 9.5 & 20.2 & 2.7 & Repeat \\
R15 & - & - & 37.2 & 7.9 & 17.7 & 1.9 & Repeat \\
R16 & - & - & 53.0 & 9.1 & 19.4 & 2.5 & Repeat \\
R16 & - & - & 36.6 & 9.0 & 20.4 & 2.3 & Repeat \\
\hline
\end{tabular}

*Group designations--Control: Cancer-free individuals, H-Normal: Hypernormal "controls" (were age 70 or older at the time of blood collection, had not reported a personal history of any cancer, and they had reported no invasive cancers in their first degree relatives at the time of blood collection, Breast Plus: Personal history of breast cancer and other type(s) of invasive cancer, Early onset: Diagnosed with breast cancer age 35 or younger, Thyroid: Personal history of thyroid cancer, Replicate: Five blinded replicate cell lines embedded in sample shipments, Repeat: 16 samples repeated, blinded as to results of earlier assays. 
Table 2: Arithmetic means of the comet parameter tail length by selected characteristics of cancer case and control groups

\begin{tabular}{|c|c|c|c|c|c|c|c|c|c|c|}
\hline \multirow{3}{*}{$\begin{array}{l}\text { Characteristic at time of blood } \\
\text { draw (1997-2003) }\end{array}$} & \multicolumn{4}{|c|}{ Control groups } & \multicolumn{6}{|c|}{ Case groups } \\
\hline & \multicolumn{2}{|c|}{$\begin{array}{l}\text { Normal } \\
\text { Controls } \\
(\mathrm{n}=49)\end{array}$} & \multicolumn{2}{|c|}{$\begin{array}{l}\text { Hyper-normal } \\
\text { Controls } \\
(\mathrm{n}=20)\end{array}$} & \multicolumn{2}{|c|}{$\begin{array}{l}\text { Breast cancer and } \\
\text { one or more } \\
\text { other cancers } \\
(n=42)\end{array}$} & \multicolumn{2}{|c|}{$\begin{array}{c}\text { Breast cancer } \\
\text { diagnosed at age } 35 \text { or } \\
\text { younger } \\
(\mathrm{n}=38)\end{array}$} & \multicolumn{2}{|c|}{$\begin{array}{l}\text { Thyroid } \\
\text { cancer } \\
\mathrm{n}=68\end{array}$} \\
\hline & $\underline{\mathrm{n}}$ & Mean $\left(\mathrm{se}^{*}\right)$ & $\underline{\mathrm{n}}$ & Mean (se) & $\underline{\mathrm{n}}$ & Mean (se) & $\underline{\mathrm{n}}$ & Mean (se) & $\underline{\mathrm{n}}$ & Mean (se) \\
\hline \multicolumn{11}{|l|}{ Age in years } \\
\hline $40-49$ & 10 & $33.0(4.0)$ & 0 & $\mathrm{NA}^{\dagger}$ & 7 & $46.7(2.3)$ & 17 & $43.4(2.0)$ & 18 & $44.0(1.9)$ \\
\hline $50-59$ & 9 & $33.0(3.4)$ & 0 & NA & 5 & $44.8(3.5)$ & 15 & $42.0(2.3)$ & 27 & $46.4(1.8)$ \\
\hline $60-69$ & 14 & $37.1(3.3)$ & 0 & NA & 13 & $45.2(3.4)$ & 5 & $40.0(4.6)$ & 15 & $48.6(1.8)$ \\
\hline $70-79$ & 9 & $36.2(2.9)$ & 15 & $29.5(2.3)$ & 11 & $42.6(2.9)$ & 1 & $48.4\left(-{ }^{+}\right)$ & 6 & $48.7(1.5)$ \\
\hline 80 or older & 7 & 34.7 (2.6) & 5 & $29.6(6.8)$ & 6 & $41.3(3.4)$ & 0 & NA & 2 & $51.7(2.1)$ \\
\hline \multicolumn{11}{|l|}{ Gender } \\
\hline Female ${ }^{\S}$ & 49 & $35.0(1.5)$ & 25 & $29.5(2.3)$ & 42 & $44.2(1.5)$ & 38 & $42.5(1.4)$ & 59 & $46.1(1.0)$ \\
\hline Malell & 0 & NA & 0 & NA & 0 & NA & 0 & NA & 9 & $50.2(2.7)$ \\
\hline \multicolumn{11}{|l|}{$\begin{array}{l}\text { Years between diagnosis of the } \\
\text { first cancer and blood collection }\end{array}$} \\
\hline $0-9$ & 0 & NA & 0 & NA & 7 & $49.0(2.4)$ & 2 & $47.3(7.6)$ & 27 & $44.4(1.7)$ \\
\hline $10-19$ & 0 & NA & 0 & NA & 13 & $40.1(2.9)$ & 19 & $42.6(1.9)$ & 17 & $46.4(2.1)$ \\
\hline $20-29$ & 0 & NA & 0 & NA & 12 & $42.9(2.3)$ & 11 & $41.1(2.7)$ & 11 & $49.6(2.0)$ \\
\hline 30 or more years & 0 & NA & 0 & NA & 10 & $47.5(3.2)$ & 6 & $43.3(3.7)$ & 13 & $49.0(1.4)$ \\
\hline \multicolumn{11}{|c|}{$\begin{array}{l}\text { Number of breast cancers reported } \\
\text { in first degree relatives }\end{array}$} \\
\hline None & 41 & $34.0(1.6)$ & 20 & $29.5(2.3)$ & 35 & $44.4(1.6)$ & 25 & $42.5(1.9)$ & 55 & $46.5(1.1)$ \\
\hline One & 7 & $37.8(3.4)$ & 0 & NA & 5 & $42.9(4.5)$ & 10 & $42.3(2.3)$ & 12 & $46.8(2.0)$ \\
\hline Two or more & 1 & $56.8(--)$ & 0 & NA & 2 & $42.2(2.9)$ & 3 & $43.5(3.8)$ & 1 & $53.4(--)$ \\
\hline \multicolumn{11}{|l|}{$\begin{array}{l}\text { Reported radiation treatment for } \\
\text { cancer (not including }{ }^{131} \text { Iodine; } \\
\text { missing data not included) }\end{array}$} \\
\hline No & 0 & NA & 0 & NA & 26 & $44.6(2.0)$ & 23 & $43.1(1.7)$ & 52 & $46.5(1.2)$ \\
\hline Yes & 0 & NA & 0 & NA & 14 & $43.3(2.0)$ & 14 & $41.1(2.4)$ & 14 & $48.0(1.7)$ \\
\hline
\end{tabular}


* SE - Standard Error

NA - Not applicable

* Cell contained only one value, standard error cannot be computed

$\S$ The differences in tail length means were borderline significantly different between controls and hypernormal controls $(\mathrm{p}=0.052)$; the means for all the case groups differed significantly from the mean for normal controls $(\mathrm{p}<$ or $=0.001)$.

$\|$ The difference in male and female mean tail length was not statistically significant $(\mathrm{p}=0.15)$. 
Table 3. Associations between comet parameters and the case groups of breast and other cancer, early-onset breast cancer (diagnosed age 35 or younger), thyroid cancer, and hyper-normal controls, among US Radiologic Technologists

\begin{tabular}{|c|c|c|c|c|c|}
\hline $\begin{array}{l}\text { Case group and } \\
\text { comet parameter* }\end{array}$ & $\begin{array}{c}\text { Number of } \\
\text { normal } \\
\text { controls }\end{array}$ & $\begin{array}{c}\text { Number of } \\
\text { cases }\end{array}$ & $\underline{\text { Adjus }}$ & odds ratios $^{\dagger}$ & $P$ for trend \\
\hline \multicolumn{6}{|c|}{ Breast and other cancer } \\
\hline \multicolumn{6}{|l|}{ Tail DNA } \\
\hline 1 & 24 & 16 & 1.0 & Referent & \\
\hline 2 & 13 & 9 & 1.3 & $0.4-4.0$ & \\
\hline 3 & 12 & 17 & 3.0 & $1.0-8.8^{\S}$ & 0.047 \\
\hline \multicolumn{6}{|l|}{ Tail length } \\
\hline 1 & 24 & 5 & 1.0 & Referent & \\
\hline 2 & 13 & 13 & 4.4 & $1.2-15.6$ & \\
\hline 3 & 12 & 24 & 10.1 & $3.0-34.6$ & $<0.001$ \\
\hline \multicolumn{6}{|l|}{ CDM } \\
\hline 1 & 24 & 12 & 1.0 & Referent & \\
\hline 2 & 13 & 13 & 1.7 & $0.6-5.0$ & \\
\hline 3 & 12 & 17 & 2.5 & $0.9-7.0$ & 0.085 \\
\hline \multicolumn{6}{|l|}{ OTM } \\
\hline 1 & 24 & 14 & 1.0 & Referent & \\
\hline 2 & 13 & 11 & 1.7 & $0.6-5.0$ & \\
\hline 3 & 12 & 17 & 3.1 & $1.1-9.1$ & 0.035 \\
\hline
\end{tabular}

\section{Early-onset breast cancer}

Tail DNA

1

2

3

Tail length

1

2

3

CDM

$\begin{array}{cccc}24 & 19 & 1.0 & \text { Referent } \\ 13 & 13 & 0.8 & 0.3-2.3 \\ 12 & 6 & 0.4 & 0.1-1.2\end{array}$

$(0.113)^{\|}$

$\begin{array}{rrrrr}24 & 7 & 1.0 & \text { Referent } & \\ 13 & 13 & 4.0 & 1.2-13.5 & \\ 12 & 18 & 4.7 & 1.5-14.8 & 0.010\end{array}$




$\begin{array}{crrrrr}1 & 24 & 28 & 1.0 & \text { Referent } & \\ 2 & 13 & 6 & 0.4 & 0.1-1.4 & \\ 3 & 12 & 4 & 0.3 & 0.1-1.1 & (0.048) \\ \text { OTM } & & & & & \\ 1 & 24 & 16 & 1.0 & \text { Referent } & \\ 2 & 13 & 13 & 1.3 & 0.4-3.9 & \\ 3 & 12 & 9 & 0.8 & 0.3-2.5 & (0.77)\end{array}$

\section{Thyroid Cancer}

Tail DNA

1
2
3

24

29

1.0 Referent

13

14

$0.8 \quad 0.3-2.1$

12

25

$1.6 \quad 0.6-3.9$

0.37

Tail length

1
2
3

24

6

1.0 Referent

13

15

$6.1 \quad 1.8-21.3$

12

47

$19.1 \quad 5.9-61.8$

$<0.001$

CDM

1

24

32

1.0 Referent

2

13

19

$1.3 \quad 0.5-3.2$

12

17

1.2

$0.5-3.2$

0.64

OTM

1
2
3

24

23

1.0 Referent

13

15

$1.2 \quad 0.4-3.1$

12

30

$2.6 \quad 1.1-6.6$

0.040

\section{“Hyper-normal” controls**}

Tail DNA

1
2
3

24

13

12

17

1.0 Referent

1

$0.2 \quad 0.0-1.5$

Tail length

1
2
3

24

13

12

0.4

$0.1-2.6$

$(0.07)$

2




$\begin{array}{cccccc}\text { CDM } & & & & & \\ 1 & 24 & 9 & 1.0 & \text { Referent } & \\ 2 & 13 & 2 & 0.3 & 0.0-1.7 & \\ 3 & 12 & 9 & 2.2 & 0.6-9.0 & 0.57 \\ \text { OTM } & & & & & \\ 1 & 24 & 16 & 1.0 & \text { Referent } & \\ 2 & 13 & 2 & 0.3 & 0.1-1.6 & \\ 3 & 12 & 2 & 0.4 & 0.1-2.3 & (0.18)\end{array}$

* Comet parameters were divided into three categories at the median and $75^{\text {th }}$ percentile of the control distribution. These cut-points were: Tail DNA (\%), 9.6 and 10.5; Tail Length $(\mu \mathrm{m}), 33.3$ and 44.0; Comet Distributed Moment (CDM; arbitrary units), 19.5 and 20.5; Olive Tail Moment (OTM; arbitrary units), 2.44 and 2.75 .

$\dagger$ Adjusted for age at the time of blood collection using three categories: 40-54, 55-74, and 75 years or older ${ }^{\ddagger} \mathrm{p}$ for trend adjusted for age and based on the continuous underlying variable

$\S$ Confidence interval excludes $1.0, P<0.05$

$\|$ Parentheses indicate a negative beta coefficient for the trend test (negative slope)

** "Hypernormal" controls were age 70 or older at the time of blood collection, had not reported a personal history of cancer (we also excluded those with non-melanoma skin cancer), and they had reported no invasive cancers in their family at the time of blood collection. 
Figure 1. Boxplots* of comet tail DNA, tail length, comet distributed moment and Olive tail moment among cases and controls ${ }^{\dagger}$, US Radiologic Technologist Study

a. Tail DNA in \%

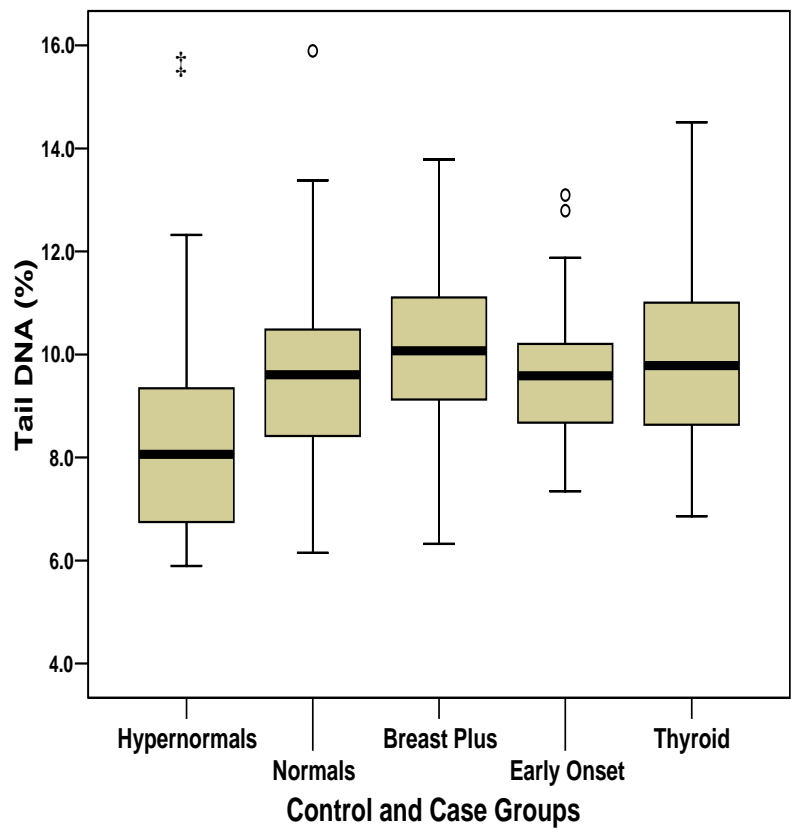

c. Comet Distributed Moment (CDM)

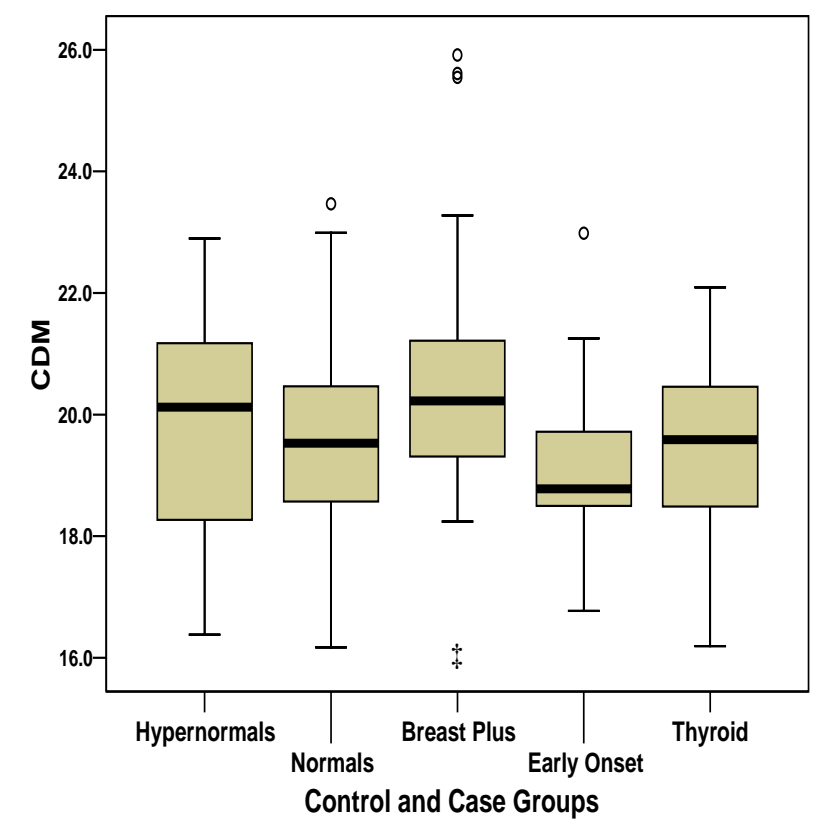

b. Tail Length in $\mu \mathrm{m}$

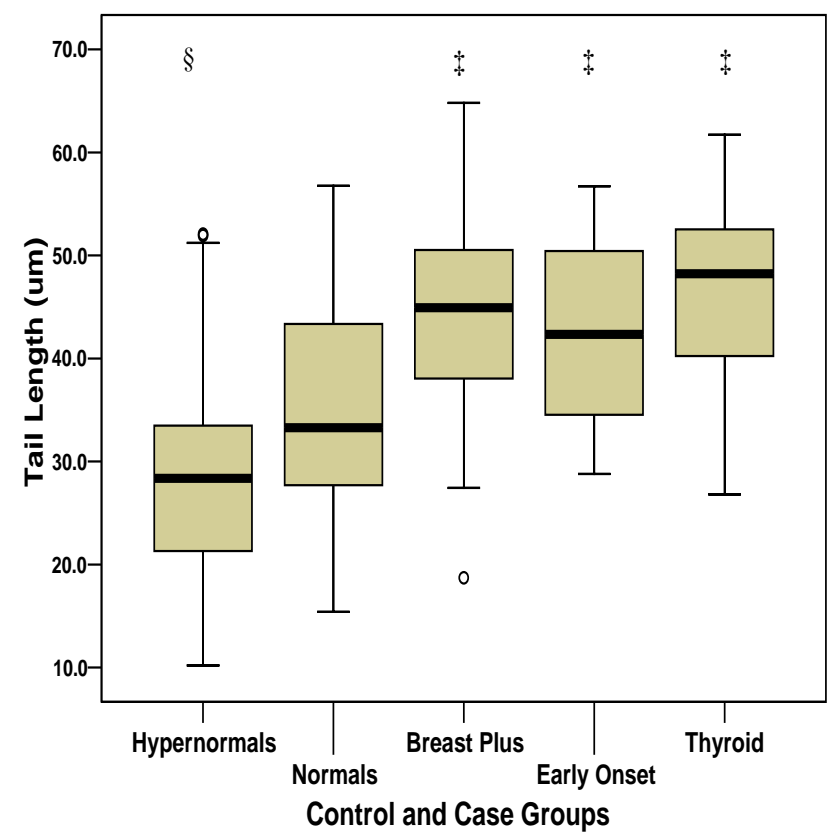

d. Olive Tail Moment (OTM)

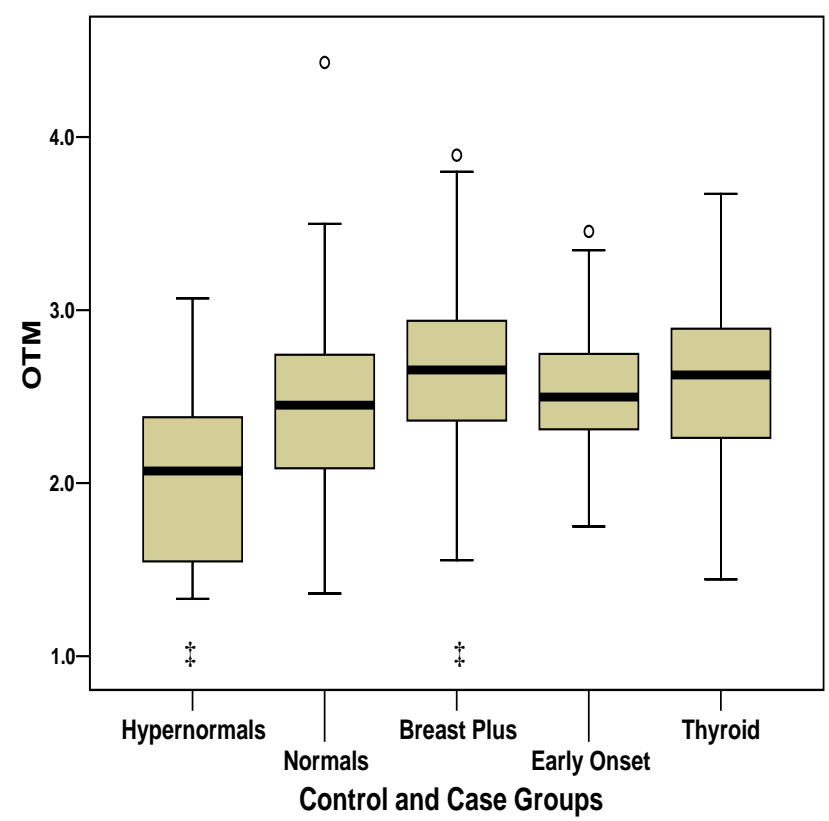

* Each boxplot represents the geometric means of the respective comet parameter of 100 cells for each individual within case or control group. The boxplots display the median (thick line), interquartile range (lower and upper box borders), the $5^{\text {th }}$ and $95^{\text {th }}$ percentiles (error bars), and extreme individual values (o). ${ }^{\dagger}$ Case and control groups are: Normal controls, $n=49$; Breast Plus (Breast cancer and other cancer), $n=42$; Early-onset (breast cancer diagnosed at age $\leq 35$ years), $n=38$; Thyroid cancer, $n=68$; Hyper-normal controls (selected as long-lived, cancer-free, no cancer reported in first-degree relatives at blood collection), $\mathrm{n}=20$. 
$\$$ The mean for the indicated group is significantly different from the mean in controls $(\mathrm{p}<0.05)$

$\S$ The mean for the indicated group is borderline significantly different from the mean in controls $(\mathrm{p}=0.052)$ 